\title{
MENABUNG SAMPAH UNTUK MASA DEPAN PADA BANK SAMPAH PAPRIKA GRAHA INDAH PAMULANG
}

\author{
Benarda $^{\mathrm{a}, 1}$, Rakhmawati Oktavianna $^{\mathrm{b}, 2}$, Silvia Sari ${ }^{\mathrm{c}, 3}$, Sevty Wahiddirani Saputri ${ }^{\mathrm{d}, 4}$, Rini Septiowati ${ }^{\mathrm{e}, 5}$ \\ a,b,c,d,e Prodi Akuntansi S1; Fakultas Ekonomi, Universitas Pamulang* \\ 1dosen01622@unpam.ac.id, 2r.oktavianna21@gmail.com, ${ }^{3}$ dosen01387@unpam.ac.id, ${ }^{4}$ dosen01468@unpam.ac.id, \\ 5dosen01402@unpam.ac.id
}

\begin{abstract}
Abstrak
Pengabdian Kepada Masyarakat yang berjudul Menabung Sampah untuk Masa Depan pada Bank Sampah Paprika Graha Indah Pamulang ini bertujuan untuk memberikan pengetahuan tentang pentingnya menabung, memberikan pelatihan menabung, mengajak serta menanamkan kesadaran kepada para pelaku bank sampah yang berada di Graha Indah Pamulang bahwa sangat besar manfaat dari menabung sampah ini untuk masa depan. Target dari pengabdian ini adalah seluruh anggota bank sampah yang terdaftar di Bank Sampah Paprika Graha Indah Pamulang. Hasil dari PKM ini terbukti ibu-ibu anggota bank sampah Kelurahan Bambu Apus dapat mengusai cara menabung dengan baik serta meningkatkan tekad dan kepedulian akan sampah di sekitar lingkungan tempat tinggal.
\end{abstract}

Kata kunci: Bank Sampah; Menabung Sampah, Masa Depan.

\begin{abstract}
Community Service entitled Saving Waste for the Future at the Graha Indah Pamulang Paprika Waste Bank aims to provide knowledge about the importance of saving, providing savings training, inviting and instilling awareness to the actors of the garbage bank in Graha Indah Pamulang that the benefits from saving this rubbish for the future. The target of this service is all members of the garbage bank registered at the Graha Indah Pamulang Paprika Waste Bank. The results of this PKM proved that the members of the garbage bank Bambu Apus Village can master how to save well and increase the determination and concern for waste around the neighborhood.
\end{abstract}

Keywords: Waste Bank, Saving, Future.

PENDAHULUAN

Penyelenggaraan Pengabdian

Kepada Masyarakat di Universitas

Pamulang (Unpam) dilakukan secara konsisten. Pelaksanaan PKM di Universitas Pamulang, di bawah kendali Lembaga Penelitian dan Pengabdian Kepada Masyarakat (LP2M). Pengabdian Kepada 
Masyarakat adalah salah satu kewajiban dari dosen sebagai wujud Tri Dharma Perguruan Tinggi, di mana memiliki tujuan untuk membantu masyarakat dalam beberapa aktivitas tanpa mengharapkan imbalan. Kegiatan PKM , biasa dilaksanakan bersama dengan mahasiswa maupun staf yang ada di perguruan tinggi.

Diharapkan dengan PKM tersebut keberadaan perguruan tinggi dapat memberikan kontribusi besar kepada pengembangan keilmuan dan pengabdian kepada masyarakat. LP2M Unpam memegang peranan yang sangat penting dalam mendorong dan mengarahkan kegiatan-kegiatan penelitian dan pengabdian kepada masyarakat sebagai wujud Tri Dharma Perguruan Tinggi. Setiap kegiatan PKM yang diselenggarkan oleh seluruh Program Studi (Prodi) di Unpam harus berkoordinasi dengan LP2M.

Kementrian Lingkungan Hidup dan Kehutanan memiliki program mengurangi jumlah sampah nasional melalui bank sampah. Direktur Jenderal Pengelolaan Limbah, Sampah, dan Bahan Beracun Berbahaya (PSLB3) KLHK Rosa Vivien Ratnawati mengatakan, perkembangan program bank sampah di seluruh Indonesia meningkat dalam kurun waktu tiga tahun terakhir.

Pada tahun 2015, jumlah bank sampah di Indonesia sebanyak 1.172 unit dan tahun 2017 jumlah bank sampah di Indonesia mencapai 5.244 unit yang tersebar di 34 provinsi dan 219 kabupaten/kota di Indonesia, Program bank sampah adalah program yang mengajak masyarakat untuk memilah sampah organik dan non-organik untuk ditukarkan menggunakan uang pada bank-bank sampah yang telah tersebar di 34 provinsi di Indonesia. Namun, ada juga bank sampah yang menerapkan penukaran sampah untuk pembayaran listrik, pembelian sembako, pembayaran biaya kesehatan, dan mendapatkan emas.

Program bank sampah itu bisa mengubah paradigma masyarakat untuk memaknai sampah sebagai sesuatu yang mempunyai nilai untuk dimanfaatkan kembali sekaligus mengurangi jumlah sampah nasional Pada bank sampah, sampah organik akan didaur ulang menjadi kompos. Sementara sampah non-organik akan diolah kembali agar bisa bermanfaat secara ekonomis. Bank sampah umumnya dibentuk di lingkungan dengan penghuni 1.000 orang dan biasanya dijalankan oleh warga kurang mampu yang ingin meningkatkan 
pendapatannya. Nasabah membawa seluruh sampah non organiknya ke bank yang diperlakukan seperti tabungan. Transaksi dicatat di buku tabungan yang dipegang oleh nasabah atau alternatifnya dicatat pada buku yang disimpan oleh bank. Banyak bank juga menerima sampah organik sementara yang lainnya mendorong pengomposan rumah tangga. Bank sampah menjual barangbarang yang ditabung kepada pengepul untuk dipergunakan kembali atau didaur ulang. Sampah yang ditabung diubah menjadi uang yang dapat ditarik jika diperlukan setelah dipotong sekitar 15\% untuk membiayai kegiatan operasional bank.

Bank sampah adalah suatu tempat yang digunakan untuk mengumpulkan sampah yang sudah dipilah- pilah. Hasil dari pengumpulan sampah yang sudah dipilah akan disetorkan ke tempat pembuatan kerajinan dari sampah atau ke tempat pengepul sampah. Bank sampah dikelola menggunakan sistem seperti perbankan yang dilakukan oleh petugas sukarelawan. Penyetor adalah warga yang tinggal di sekitar lokasi bank serta mendapat buku tabungan seperti menabung di bank.

Tidak semua warga dan pelaku Bank Sampah di Graha Indah Pamulang memaknai menabung sampah bisa mendatangkan keuntungan di masa depan dan solusi yang sangat tepat untuk permasalahan sampah di Indonesia saat ini. Bank sampah Paprika di Graha Indah Pamulang ini sudah lama berdiri dan kegiatan menabung sampah tersebut berlangsung kontinyu, hanya saja perlu adanya pengembangan sistem pembukuan menurut kami yang perlu dibenahi agar kegiatan tersebut bertambah baik dan lebih maju lagi.

Prinsip pemberdayaan masyarakat yang paling baik adalah kelompok yang memang lahir dari kebutuhan dan kesadaran masyarakat sendiri, dikelola, dan dikembangkan dengan menggunakan terutama sumber daya yang ada di masyarakat tersebut, dan memiliki tujuan yang sama. Sehingga kegiatan Pengabdian Kepada Masyarakat (PKM) ini sangat relevan dan merupakan bagian dari pada kegiatan pendampingan dengan tetap ditunjukkan kepada penguatan kapasitas kelompok sehingga kelompok PKM bisa membangun kultur kelompok yang lebih terbuka, adil, bertanggung jawab dan mandiri. Melihat lokasi kampus yang tidak jauh dengan lokasi PKM, maka sudah menjadi kewajiban bagi perguruan tinggi untuk ikut serta membantu berbagai 
persoalan yang dihadapi masyarakat. Sudah selayaknya kehadiran perguruan tinggi agar dapat benar-benar dirasakan manfaatnya oleh masyarakat baik yang dekat maupun yang jauh.

Secara umum kegiatan ini bertujuan untuk menambah ilmu kepada para pelaku Bank Sampah Paprika yang berada di Graha Indah Pamulang melalui pemberian informasi dan pengetahuan mengenai pelatihan menabung. Secara khusus pengabdian kepada masyarakat ini bertujuan memberikan peluang dan trik yang dapat mengatasi persalahan sampah di Indonesia.

Sasaran dari kegiatan PKM kali ini adalah para pelaku Bank Sampah di Graha Indah Pamulang. Jumlah anggota sendiri ada kurang lebih 100 orang, namun pada kegiatan kali ini kami hanya mengundang beberapa perwakilan saja. Diharapkan dengan adanya kegiatan ini, anggota yang telah hadir bisa menularkan pengetahuan dan ketrampilannya kepada anggota lainnya. Hal positif yang terlihat nyata adalah ketika para anggota bank sampah dengan penuh kesadaran ingin mengurangi pencemaran yang berasal dari limbah rumah tangga dan keinginan untuk terus menabung sampah.

\section{METODE}

Kerangka pemecahan masalah pada kegiatan

\section{Pengabdian Kepada Masyarakat yang}

dilakukan meliputi :

1. Studi Pendahuluan, di mana sebelumnya tim kami sudah pernah melakukan PKM pada pengelola bank sampah yang berada di wilayah kelurahan Bambu Apus Pamulang dengan tema pelatihan mengenai pembukuan untuk mempermudah pelaporan dari kegiatan bank sampah yang ada. Lalu kami mendapatakan kebutuhan dari pada pengelola bank sampah, di mana mereka ingin membuat suatu produk atau barang yang memiliki nilai ekonomis lebih dari sampah yang sudah mereka kumpulkan karena selama ini, sampah-sampah tersebut langsung dibawa oleh pengepul sampah tanpa menghasilkan sebuah produk atau barang.

2. Identifikasi Masalah, kami mencari referensi produk atau barang yang bisa dihasilkan dari sampah yang telah dikumpulkan oleh para anggota bank sampah. Untuk saat ini sampah yang ada dipilah oleh para anggota agar bisa memiliki nilai ekonomis lebih. Setiap sampah memiliki nilai yang berbeda. Biasanya sampah 
dibuang dijadikan satu di dalam bak sampah dan bisa menumpuk tanpa ada manfaatnya.

3. Tujuan Pengabdian Kepada Masyarakat, tujuan dari PKM kali ini adalah memanfaatkan sampah yang ada kemudian dipilah sesuai dengan jenis-jenis sampah dan bisa memiliki nilai ekonomis yang berbeda. Sampah tersebut juga bisa menjadi sesuatu yang lebih bermanfaat dan bisa mengurangi pencemaran lingkungan. Produk yang dihasilkan diupayakan yang aman digunakan dan bisa memiliki nilai ekonomis. Dalam hal ini, diharapkan para anggota bank sampah bisa mendapatkan tambahan pendapatan dengan menabung sampah

Anggota bank sampah diberikan pengetahuan mengenai pemanfaatan sampah yang ada bisa ditabung setelah dipilah sesuai kriteria yang ada. Karena tiap jenis sampah memiliki nilai ekonomis yang berbeda. Pemberian materi secara intens dan berkelanjutan memberikan manfaat dan dampak positif yang besar kepada masyarakat yang memiliki akses minimum pada beberapa bidang kehidupan mereka. Para anggota bank sampah diberikan pengetahuan dan ketrampilan bagaimana memilah sampah yang ada dan bisa ditabung.

Target audiens atau sasaran yang dituju dalam Pengabdian Kepada Masyarakat ini adalah para anggota bank sampah yang berada di komplek perumahan Graha Indah Pamulang. Anggota dari bank sampah tersebut secara keseluruhan ada kurang lebih 100 orang namun saat dilakukan PKM ini, kami hanya mengundang sekitar 30 orang saja dan diharapkan nantinya akan menularkan ilmu dan pengetahuan yang sudah didapatkan.

Wilayah sasaran dalam PKM kali ini adalah komplek perumahan Graha Indah Pamulang yang masuk dalam kelurahan Bambu Apus Pamulang, di mana bank sampah di wilayah kelurahan tersebut para anggotanya cukup aktif dan cukup berkembang.

Para anggota bank sampah sendiri, kebanyakan adalah para wanita dan sebagian besar mereka berprofesi sebagai ibu rumah tangga.

Pengabdian kepada masyarakat ini diselenggarakan pada :

Tanggal : 27-29 Juni 2020

Tempat : Graha Indah Pamulang 
atau bukti-bukti lain sesuai dengan jenis

Peserta : Anggota Bank Sampah Graha

Indah Pamulang

Kegiatan pengabdian kepada masyarakat dilaksanakan oleh para dosen S1 prodi Akuntansi dari Universitas Pamulang sesuai kebutuhan dalam masyarakat dan memberikan manfaat nyata baik secara langsung atau tidak langsung.

Kegiatan PKM ini sendiri melibatkan para pihak internal maupun eksternal, dalam sebuah kerjasama yang menyesuaikan dengan realitas lapangan tanpa harus menghilangkan tujuan awal yang hendak dicapai serta berkelanjutan, dalam arti kegiatan pengabdian dapat dikembangkan lebih lanjut secara mandiri.

Dosen yang akan melaksanakan PKM, atas inisiatif sendiri ataupun untuk memenuhi permintaan dari luar, mengajukan surat pemberitahuan kepada Ketua LPPM dengan sepengetahuan dan persetujuan Ketua Program Studi dan Dekan, dilengkapi dengan rencana kegiatan (Proposal). Ketua LPPM menerbitkan surat tugas bagi dosen yang akan melaksanakan PKM. Setelah kegiatan selesai, dosen pelaksana PKM melaporkan hasil kegiatannya, disertai bukti-bukti fisik seperti: presensi peserta, handout, modul, sertifikat, dokumentasi berupa foto kegiatan kegiatannya.

\section{HASIL DAN PEMBAHASAN}

Berdasarkan hasil observasi terdapat tempat Bank Sampah Graha Indah Pamulang. Usaha atau bisnis ini dilakukan oleh kaum wanita atau ibu rumah tangga dan pemuda pemudi yang ingin membantu menambah keuangan keluarga. Graha Indah Pamulang sengaja kami jadikan tempat untuk penyelenggaraan/menjadi mitra dalam PKM yang diajukan lebih lanjut beberapa masalah yang dihadapi dalam pengelolaan sampah.

Yang menjadi masalah dalam pengabdian masyarakat di Graha Indah Pamulang adalah banyaknya sampah yang selama ini langsung dibuang ke TPA tanpa adanya pemilahan sampah yang ternyata masih bisa dimanfaatkan dan bisa dijual kembali menghasilkan uang. 


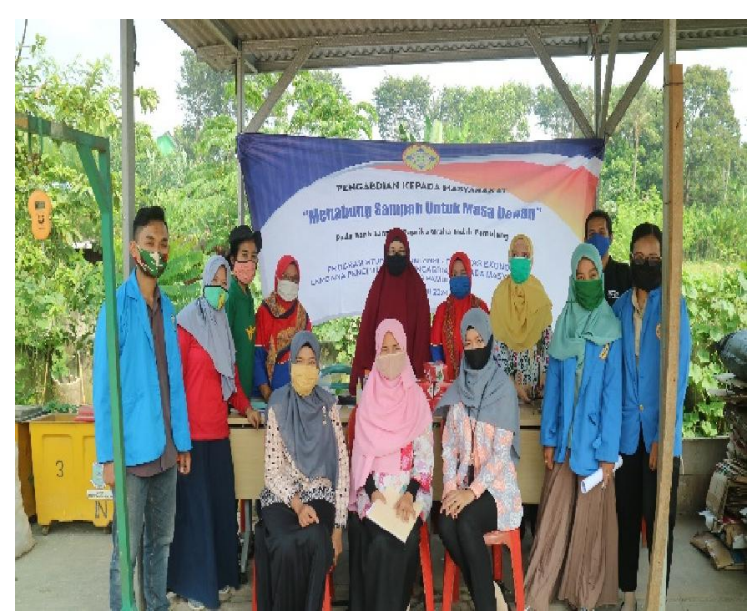

Gambar 1. Peserta PKM, Mahasiswa dan Narasumber

Sampah yang menunpuk setiap hari juga menjadi masalah bagi masyarakat sehingga dalam hal ini kami memberikan penyuluhan kepada masyarakat Graha Indah Pamulang untuk lebih peduli pada lingkungan dengan memilah sampah dan bisa menjadikan tabungan masa depan dari hasil penjualan sampah tersebut. Dengan adanya PKM ini dapat memberikan pembelajaran kepada masyarakat khususnya di Graha Indah Pamulang dalam meningkatkan kesehatan lingkungan melalui menabung sampah yang sudah dipilah sesuai kriteria.

Program pengabdian ini disusun berdasarkan hasil survey pendahuluan oleh TIM PKM ke lokasi yang akan dijadikan kegiatan penyuluhan serta wawancara dengan kepala pengurus dari Bank Sampah Paprika, Graha Indah - Pamulang. Seiring dengan pertumbuhan penduduk yang semakin meningkat akan berdampak pula pada peningkatan permintaan bahan kebutuhan sehari-hari. Dari situlah sampah terus meningkat.

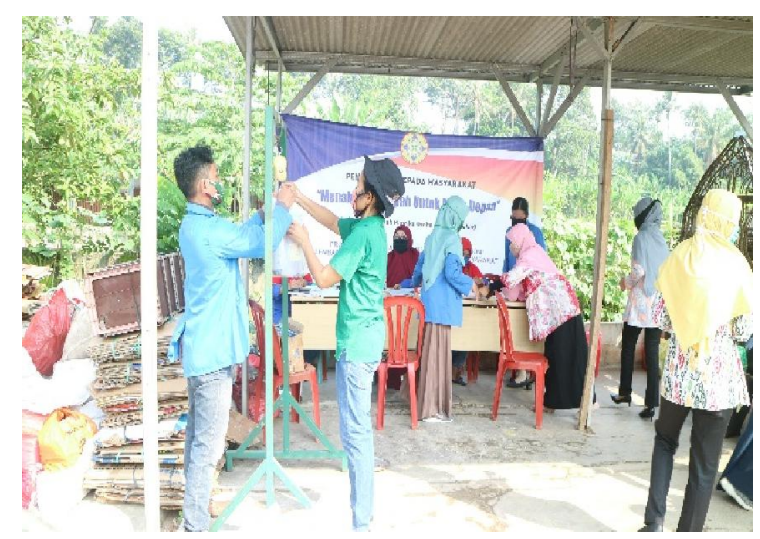

Gambar 2. Proses penimbangan dan pencatatan di Bank Sampah

Bank sampah adalah suatu tempat yang digunakan untuk mengumpulkan sampah yang sudah dipilah-pilah. Hasil dari pengumpulan sampah yang sudah dipilah akan disetorkan ke tempat pembuatan kerajinan dari sampah atau ke tempat pengepul sampah. Bank sampah dikelola menggunakan sistem seperti perbankan yang dilakukan oleh petugas sukarelawan Penyetor adalah warga yang tinggal di sekitar lokasi bank serta mendapat buku tabungan seperti menabung di bank. Prinsip pemberdayaan masyarakat yang paling baik adalah kelompok yang memang lahir dari kebutuhan dan kesadaran masyarakat 
sendiri, dikelola, dan dikembangkan dengan menggunakan terutama sumber daya yang ada di masyarakat tersebut, dan memiliki tujuan yang sama. Sehingga kegiatan Pengabdian Kepada Masyarakat (PKM) ini sangat relevan dan merupakan bagian dari pada kegiatan pendampingan dengan tetap ditunjukkan kepada penguatan kapasitas kelompok sehingga kelompok PKM bisa membangun kultur kelompok yang lebih terbuka, adil, bertanggung jawab dan mandiri. Melihat lokasi kampus yang tidak jauh dengan lokasi PKM, maka sudah menjadi kewajiban bagi perguruan tinggi untuk ikut serta membantu berbagai persoalan yang dihadapi masyarakat. Sudah selayaknya kehadiran perguruan tinggi agar dapat benar-benar dirasakan manfaatnya oleh masyarakat baik yang dekat maupun yang jauh.

\section{KESIMPULAN}

Sampah sudah menjadi permasalah bagi kita semua yang harus segera dicarikan solusinya dan salah satu cara yang cukup efektif adalah dengan mendirikan Bank Sampah. Volume sampah setiap hari terus meningkat, dengan kehadiran bank sampah yang menerapkan konsep 3R (Reuse, Reduce, dan Recycle) sangat efektif karena ada keterlibatan warga secara aktif dimana warga bisa langsung memilah sampah yang ada. Sampah yang tadinya tidak bernilai bisa di ubah menjadi memilki nilai jual. Bank sampah adalah suatu tempat yang digunakan untuk mengumpulkan sampah yang sudah dipilah- pilah. Hasil dari pengumpulan sampah yang sudah dipilah akan disetorkan ke tempat pembuatan kerajinan dari sampah atau ke tempat pengepul sampah. Bank sampah dikelola menggunakan sistem seperti perbankkan yang dilakukan oleh petugas sukarelawan Penyetor adalah warga yang tinggal di sekitar lokasi bank serta mendapat buku tabungan seperti menabung di bank.

Bank sampah di Graha Indah Pamulang ini sudah lama berdiri dan kegiatan menabung sampah tersebut berlangsung kontiniu, hanya saja perlu adanya pengembangan sistem pembukuan menurut kami yang perlu dibenahi agar kegiatan tersebut bertambah baik dan lebih maju lagi, maka para dosen prodi S1 Akuntansi Universitas Pamulang melakukan Pengabdian Kepada Masyarakat untuk membantu para pelaku Bank Sampah yang berada di Graha Indah Pamulang.

Pelaksanaan kegiatan PKM ini diharapkan tetap dilakukan secara rutin di Graha Indah Pamulang, dengan mengusung 
tema yang berkelanjutan, baik Ekonomi, sosial dan lingkungan sehingga menjadikan Indonesia menjadi bebas sampah.

\section{REFERENSI}

Aboejoewono, A. (1985). Pengelolaan Sampah Menuju ke Sanitasi Lingkungan dan Permasalahannya. Jakarta: Wilayah DKI Jakarta Sebagai Suatu Kasus.

Dwiyatmo, K. (2007). Pencemaran Lingkungan dan Penanganannya. Yogyakarta: Citra Aji Parama.

Gelbert, M. (1996). Konsep Pendidikan Lingkungan Hidup dan Wall Chart. Dalam Buku Panduan Pendidikan Lingkungan Hidup . Malang: PPPGT/VEDC.

Hadiwiyoto, S. (1983). Penanganan dan Pemanfaatan Sampah. Jakarta: Yayasan Idayu.
Hambali, A., \& Bambang. (2008). Pendidikan Karakter Berbasis AlQuran. Bandung: Simbiosa Pekatama Media.

Hardjasoemantri, K. (2005). Hukum Tata Lingkungan. Yogyakarta: Gajah Mada University Press.

Ilham. (2012, Mei 24). Konsep dan Arah Pengembangan Siswa Pecinta Lingkungan Hidup. Diambil kembali dari blogspot: http://illangtanete84.blogspot.com

Kartikawan, Y. (2009). Pengelolaan Sampah. Jurnal Lingkungan Hidup.

Priyadi, E. S., Fitriyah, Suryani, E., \& Juitania. (2019). Program Pengajaran dan Pelatihan Bahasa Inggris dan MatematikaDasar di Yayasan AlKamilah Kelurahan Serua Kecamatan Bojongsari Kota Depok. Abdimisi vol.1 no.1 Desember, 3140 